\title{
Development of Learning Tools by Applying The MASTER Plan Technique Based on A Scientific Approach to Improve Student Learning Outcomes on Number Pattern Material
}

\author{
Herni Purnamawati, Atma Murni, Sehatta Saragih \\ Program Studi Magister Pendidikan Matematika, Universitas Riau \\ herni.purnamawati7381@grad.unri.ac.id
}

\begin{abstract}
This research is motivated by the lack of optimal learning outcomes of students due to the lack of learning devices that are considered being able to train students' abilities in solving problems. The purpose of this study is to develop mathematics learning tools that meet the validity, practicality, and effectiveness requirements to improve the learning outcomes of grade VIII students of SMP / MTs on material number patterns. The development model used is the ADDIE model for designing learning systems. The instruments used were syllabus validation instruments, RPP, LKPD, practicality instruments and effectiveness instruments. The technique used is the technique of collecting observation data, interviews, questionnaire documentation and tests. Mathematics learning to use the MASTER Plan technique based on a scientific approach is already valid with the results of syllabus validation $84.25 \%$, RPP $90.30 \%$, LKPD $86.50 \%$. This learning device fulfills the practical requirements for large group trials with an average of $93.52 \%$ results and an average student questionnaire response rate of $95.66 \%$. The use of effective learning tools to improve student learning outcomes for KKM achievement is $83.33 \%$.
\end{abstract}

Keyword: Learning Tools, MASTER Plan Techniques, Learning Outcomes.

\section{INTRODUCTION}

Education is a series of complex events, which are a series of communication activities between humans, so that humans grow as whole people. In Law Number 20 Year 2003 it is stated that education is a conscious and planned effort to create an atmosphere of learning and learning process so that students actively develop their potential to have spiritual, religious, self-control, personality, intelligence, noble character, and skills that are it needs itself, society, nation and state. Furthermore, the core of education is learning tools, so the quality of learning tools is one of the main factors determining the quality of education.

The learning process in the concept of communication is basically a process of communication between the teacher and students, between students and students and between students and learning resources (Widada et al., 2020); (Akinloye et al., 2020). A learning process is said to be good, if the communication that occurs in learning is able to cause a high intensity of the learning process (Li et al., 2020); (Si et al., 2020). In other words, the communication that occurs must be able to provide facilities for students to carry out the learning process efficiently and effectively by implementing learning that is guided by a predetermined curriculum. In the 2013 curriculum, it was determined that 
what was used was a scientific approach. A scientific approach is a basic concept that inspires or underpins the formulation of teaching methods by applying scientific characteristics (Kemdikbud, 2013). The learning process touches three domains, namely attitudes, knowledge, and skills. The end result is an increase and balance between the ability to be good human beings (soft skills) and humans who have the skills and knowledge to live properly (hard skills) from students which include competency aspects of attitudes, skills, and knowledge (Kemdikbud, 2013).

The scientific learning approach is a learning activity that adapts the steps of scientists in obtaining attitudes, knowledge, and skills through scientific methods (Persada et al., 2020). Learning to use a scientific approach is not just a transfer of knowledge from the teacher to students, but students from their own knowledge (Saylendra \& Danial, 2015). Through a scientific approach, students obtain attitudes, knowledge, and skills as well as the scientific method carried out by scientists (Asmawati \& Nurhayati, 2016). To implement the scientific approach in mathematics, learning requires learning methods and techniques that support so that learning activities with the scientific approach can be implemented well (Tambunan, 2019); (Erita, 2013). A teacher should be able to create conditions and situations that allow students to understand the meaning of learning materials through the learning process and store in memory that can be processed at any time and further developed (Murda \& Purwanti, 2017). The success of a teacher in learning is expected, to meet these objectives requires a careful preparation. Before teaching a teacher is expected to prepare materials to be taught, prepare teaching aids that will be used, prepare questions and directions to lure students to actively learn, learn the situation of students, understand the weaknesses and strengths of students, and learn the knowledge of students, all the implementation will be decomposed in the learning device (Legendari \& Raharjo, 2016).

Teacher demands to develop the learning tool researchers conducted interviews with 7 junior high school mathematics teachers in Pekanbaru. Interviews conducted include aspects of developing learning tools used by teachers in the learning process. Related to the RPP and LKPD tools, from the interview results obtained information that the difficulties felt by the teacher in compiling a device that is in accordance with the 2013 curriculum is that teachers find it difficult to link the scientific approach with the learning model to be used. The teacher prefers a practical way in compiling learning tools by downloading lesson plans from the internet, asking fellow mathematics teachers and using lesson plans from MGMP. In addition, teachers have difficulty in preparing LKPD that can encourage participants to find their own concepts from the material being studied in order to solve the given problem. One solution provided is to apply the MASTER Plan technique based on a scientific approach. The goal is to use appropriate learning techniques that are expected to increase learning outcomes, and motivation to learn can increase. 
According to Rose and Nichol the MASTER Plan technique is also called accelerated learning (Haris Mudjiman, 2006). The MASTER Plan technique consists of six stages of learning: (1) motivate your mind, (2) acquiring the information, (3) searching out the meaning, (4) triggering the memory (lock facts in memory), (5) exhibiting what you know (show others), (6) reflecting on how you've learned (reflection) (Muhammad Tajuddin, Endang Siti Astuti, Hamdani Husnan, 2015). The MASTER Plan technique based on a scientific approach was designed in this study as shown in Table 1.

Table 1. The Design of MASTER Plan Techniques is Based on A Scientific Approach

\begin{tabular}{|c|c|c|}
\hline $\begin{array}{l}\text { Learning Curriculum } \\
2013 \\
\end{array}$ & Scientific approach & MASTER Technique Plan \\
\hline \multirow[t]{3}{*}{ Preliminary activities } & - & $\begin{array}{l}\text { Step-1 } \\
\text { Motivate your mind } \\
\text { (grow motivation) }\end{array}$ \\
\hline & Observe & - \\
\hline & Ask & $\begin{array}{l}\text { Step-2 } \\
\text { Acquiring the information (gathering information) }\end{array}$ \\
\hline \multirow[t]{4}{*}{ Core activities } & Collecting information & \\
\hline & Reasoning & $\begin{array}{l}- \\
\text { Step-3 }\end{array}$ \\
\hline & & $\begin{array}{l}\text { Searching out the meaning (find meaning) } \\
\text { Step- } 4 \\
\text { Triggering the memory } \\
\text { (lock facts in memory) }\end{array}$ \\
\hline & Communicating & $\begin{array}{l}\text { Step-5 } \\
\text { Exibiting what you know (show others) } \\
\text { Step-6 } \\
\text { Reflecting on how youve learned }\end{array}$ \\
\hline Closing activities & - & \\
\hline
\end{tabular}

Widdiharto states students tend to use the ability to memorize formulas without understanding their intentions, including when learning number patterns (Dina \& Arifatud Dina, 2015). Researchers hope that by applying independent learning with MASTER Plan techniques based on a scientific approach, especially in the material number patterns learners can not only memorize formulas but can also understand and interpret, apply the formula that has been observed and found to solve learning problems independently so that it can improve results learned learners. Therefore, researchers are interested in developing learning tools by applying the MASTER PLan technique to improve student learning outcomes in the material of valid, practical and effective number patterns. 


\section{RESEARCH METHOD}

The development model used in this study is the ADDIE model. ADDIE development model is an abbreviation of Analysis, Design, Development, Implementation, and Evaluation which is the stage of development of learning tools. The ADDIE model is a model that can adapt very well in various conditions, the level of flexibility of this model in answering problems is quite high, effectively used, and provides a general and structured framework (N. W. Siwardani, N. Dantes, 2015). The subjects of this study were students of class VIII SMP / MTs Ummatan Wasathan.

The first stage of the ADDIE model is the analysis phase. The analysis conducted is a performance analysis (performance analysis) and a needs analysis (need analysis). Performance analysis is carried out to find out the difficulties encountered by the teacher in the learning process. Needs analysis is done to find out the problems faced by students in learning. The second stage is the design stage. At this stage, collecting relevant references as material to design learning tools on the material number patterns. The design of learning tools is adjusted to the Basic and Secondary Education Process Standards and applies the MASTER Plan technique based on a scientific approach. The third stage is the development stage, which is the stage of producing or realizing syllabus, RPP, and LKPD designs that have been determined. Learning devices that have been produced are then validated by experts. The learning device validation was carried out by three mathematics education lecturers. The results of the validation carried out are further analyzed and revised according to the suggestions of the validator. The fourth step is the implementation phase or testing of learning tools. Learning devices that have been said to be valid are then tested. The trial was conducted on a small group of 8 people with heterogeneous abilities aimed at seeing the readability of LKPD and large groups of 16 people who aimed to find out the practicality level of learning tools that had been developed. The fifth stage is the evaluation stage. The evaluation phase is carried out in two forms, namely formative and summative evaluation. Formative evaluations are carried out at the end of each face-toface meeting and summative evaluations are carried out after the activity ends as a whole.

Analysis of the data in this study is the validation sheet analysis, response questionnaire analysis, and analysis of minimum completeness criteria test results. Validation sheet analysis is obtained by determining the average percentage of validation from the validator. Table 2 is a category of learning device validity (Akbar, 2013).

Table 2. Categories of Validity of Learning Devices

\begin{tabular}{cc}
\hline Validity Criteria & Validity Level \\
\hline $85,01 \%-100,00 \%$ & Very Valid \\
$70,01 \%-85,00 \%$ & Valid \\
$50,01 \%-70,01 \%$ & InValid \\
$01,00 \%-50,00 \%$ & InValid \\
\hline
\end{tabular}


Response questionnaire analysis is obtained by determining the level of practicality, which is the score obtained divided by the highest score and multiplied by $100 \%$. Table 3 is a category of learning device validity (Akbar, 2013).

Table 3. Practicality Categories of Learning Devices

\begin{tabular}{cc}
\hline Interval & Category \\
\hline $85,01 \%-100,00 \%$ & Very practical \\
$70,01 \%-85,00 \%$ & practical \\
$50,01 \%-70,00 \%$ & Not practical \\
$01,00 \%-50,00 \%$ & Not practical \\
\hline
\end{tabular}

Data on learning outcomes in this study were obtained from tests of students' mathematical problem-solving abilities after using the learning tools developed. Learning outcomes data are used to see the effectiveness and impact of the use of learning tools. The impact of the use of learning tools is seen from the difference in the average mathematical problem solving ability of students in the experimental class and the control class obtained from the results of the pretest and posttest.

The effectiveness of learning devices is obtained by looking at the achievement of learning objectives. In the 2013 curriculum, the standard measure of the achievement of learning objectives is the achievement of the KKM. In line with that, the effectiveness of learning tools is based on the KKM achievement. The learning device is said to be effective if the percentage of student learning outcomes tests reaches the classical learning completeness criteria that is $\geq 75 \%$ (Rahmadi, 2015). Average different test is done to see the improvement of students' mathematical problem-solving abilities as seen from the results of the pretest and posttest results. Pretest and posttest data analysis was performed to find out whether there were differences in students' mathematical problem-solving abilities before and after the use of the learning tools developed. Difference test is done by t-test. The developed learning device is said to be able to improve students' mathematical problem-solving abilities of the value of $\mathrm{p}<\alpha=0.05$.

\section{RESULTS AND DISCUSSION}

The learning tools produced in this study were in the form of syllabus, lesson plans, and LKPD on the material grade VIII SMP / MTs numbers. The device developed was a learning device with a MASTER Plan technique based on a scientific approach. The development of mathematics learning tools for grade VIII SMP was designed using the ADDIE model. This model, as the name implies, consists of five phases or stages, namely (A) analysis, (D) design, (D) e-development, (I) implementation, and (E) valuation. In the analysis phase, performance analysis and needs analysis are conducted. In the 
performance analysis stage, the researchers conducted interviews with several mathematics teachers.

Based on the interview results it was found that the equipment used by the teacher was not in accordance with the 2013 curriculum, the teacher was still having difficulty in compiling learning tools that were in accordance with the 2013 curriculum, the model or method used had not been varied, the LKPD used had not been able to assist students in finding concepts from the material studied and student learning outcomes are still not achieving maximum results. At the needs analysis stage Needs analysis is done by observing and interviewing students during the mathematics learning process of number pattern material. Based on observations and interviews, it is known that the involvement of students in mathematics learning number pattern material is still low. In this study the learning tool was arranged for 4 meetings. The tools are arranged using the MASTER Plan technique. The chosen MASTER Plan technique is tailored to the needs of students who have not maximally studied independently. The design phase is the design phase of learning tools in the form of syllabus, lesson plans and LKPD. The syllabus and RPP designs are adjusted to the syllabus and RPP components of Permendikbud No. 22 of 2016. Learning activities on the syllabus and RPP are prepared based on MASTER plan techniques based on a scientific approach.

The draft LKPD is adjusted to the requirements of a good LKPD. LKPD was prepared using the steps of a MASTER plan technique based on a scientific approach. The draft LKPD consists of a cover, LKPD contents and practice questions. The contents of LKPD are adjusted to the MASTER Plan technical steps. The designed LKPD begins with a problem that can motivate students to learn it because they know the benefits of the material to be learned. The problem is adjusted to the material learned at each meeting. The following covers LKPD that uses the MASTER Plan technique based on a scientific approach.

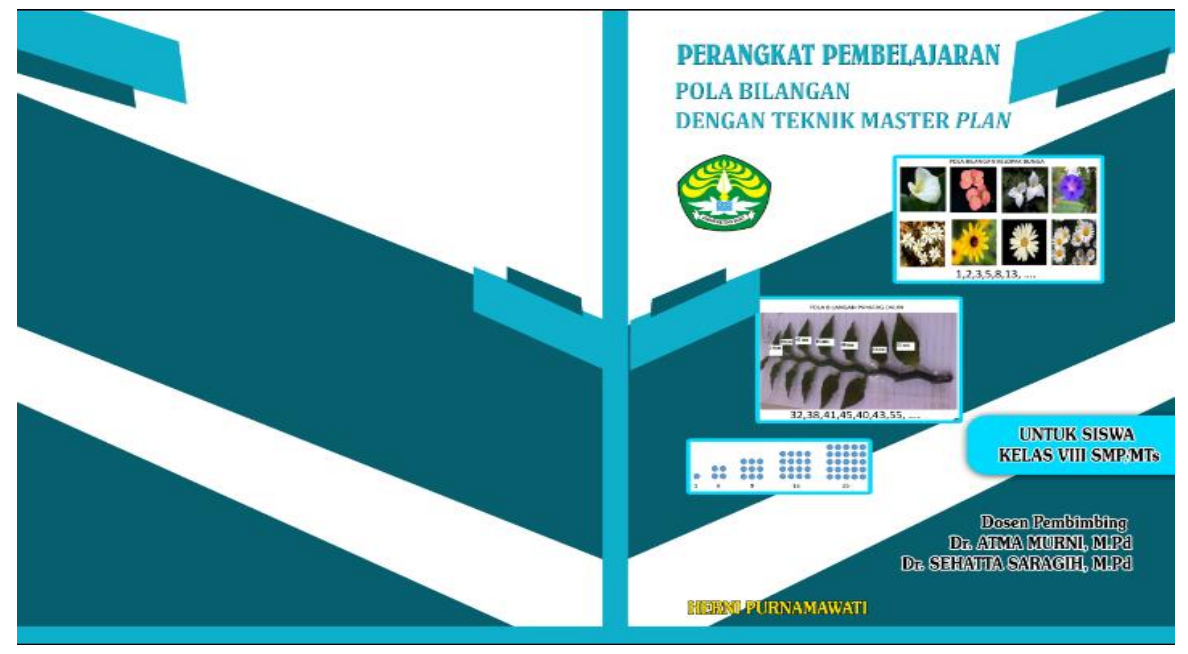

Figure 1. LKPD Cover 
The development phase is the stage of developing learning tools that have been prepared. This stage is the stage for producing development products through expert validation followed by revisions. The results of the assessment of the validator on several aspects used in the syllabus, namely the aspect of the content of $87.93 \%$ which means valid, and the construction aspect $80.56 \%$ which means valid. So that obtained an average total assessment of the validator that is $84.25 \%$ means that the syllabus developed is in the category of "valid". The syllabus developed is in accordance with the syllabus component of Permendikbud No. 22 of 2016. However, there are some suggestions for improvement of the validator, namely the syllabus included in the school location, it should also be included in the $5 \mathrm{M}$ learning activities, so that it looks based on a scientific approach.

The results of the assessment of the validator of RPP-1 91.08\% which means "very valid", RPP-2 91.08\% which means "very valid", RPP-3 91.08\% which means "very valid" and RPP-4 91.08\% which means it is very valid. So the average total rating of the validator of the developed lesson plan is $91.08 \%$, meaning that the developed lesson plan is in the "very valid" category. The RPP is in accordance with the RPP component in Permendikbud No. 22 of 2016. However, there are a number of suggestions for improvement from the validator, one of them is that the LKPD words in the RPP are replaced with learning activities carried out in class and in the RPP the school location is included.

The results of the assessment of the validator of LKPD-1 $86.50 \%$ which means "very valid", LKPD-2 86.50\% which means "very valid", LKPD-3 86.50\% which means "very valid", LKPD-4 86.50\% which means "very valid". In order to obtain an average total rating of the validator of the developed LKPD that is $86.50 \%$ it means that the developed LKPD is in the "very valid" category. The developed LKPD has fulfilled the requirements of a good LKPD. This is reinforced by the results of research that says that the quality of the product is seen from its validity, practicality, and effectiveness (Musa Thahir, Yenita Roza, 2018). LKPDs that were prepared were of good quality if they met didactic, construction, and technical requirements (Fitri Nurhayati, Joko Widodo, 2015); (Heni Rahmadani, Yenita Roza, 2020) and (Thahir et al., 2020). However, there are some suggestions for improvement of the validator, namely problems in LKPD, the words "Can" be replaced with the words "How", adjust the background color to the color of the writing, font size and writing improved.

The implementation phase is the test phase of learning tools that have been developed. The trials conducted were small group trials to see the readability of the developed LKPD, while the large group trials were to see the practicality and effectiveness of the learning tools developed. Based on the response questionnaire, it was found that the average assessment of students was $95.64 \%$ meaning that the readability of LKPD developed "very practical" was used by students. Although the readability results show that the LKPD that was developed was very practical, but the researchers still made several revisions to facilitate students in working on LKPD. 
After conducting small group trials, researchers conducted large group trials to see the practicality and effectiveness of the learning tools developed. Learning tools are said to be good if the achievement of learning performance / teacher's ability to manage learning is at least good enough (Novrini, Siagian, P., \& Surya, 2015). Based on the results of practicality from the observation sheet the implementation of teacher activities in applying a scientific approach all aspects have been implemented well with an average yield of $93.06 \%$. However, in the closing activity, namely the provision of formative tests which were planned to be conducted were not carried out well in several meetings, this was due to insufficient time.

Researchers also gave questionnaire responses to all students present to determine the practicality of LKPD. Based on student response questionnaire obtained that the average student response questionnaire to the practicality of LKPD-1 was $91.3 \%$ meaning the device developed was "very practical" to be used, LKPD-2 was 93\% meaning the device developed was "very practical" to be used, LKPD-3 is $95 \%$ meaning the device developed was "very practical" to be used, and LKPD-4 was 96.6\% meaning the device developed was "very practical" to use. Students state that the developed LKPD can help students in understanding problems and solving problems of number patterns in daily life. In addition, the developed LKPD can also assist students in finding a settlement strategy in the form of a number pattern formula. This is in accordance with the function of LKPD according to Prastowo (Isna Rafianti, 2018) that this LKPD can facilitate students in understanding the material provided.

After testing a large group to see the practicality of the learning device, the researcher then looks at the effectiveness of the learning device developed. This effectiveness test was conducted on two classes, namely class VIII pi, which is an experimental class of 18 people with heterogeneous abilities, and class VIII pa 2, which is a control class of 18 people with heterogeneous abilities. In the experimental class, the learning process uses learning tools that researchers have developed while the control class uses pre-existing devices. In this effectiveness trial the researcher gives pretest and posttest to students. Pretests are given before students use the learning tools developed. Posttest is given after the students use the developed learning tool.

The effectiveness of learning tools developed can be seen from the completeness of students' learning outcomes tests in a classical way. Then the average difference in the ability to solve problems between the experimental class and the control class was carried out. This test is conducted to see an increase in students' mathematical problem-solving abilities. Based on the completeness of the test results obtained by the percentage of students who reach the KKM after the use of mathematics, learning tools developed was $83.33 \%$. Thus the learning tools developed are effective for improving student learning outcomes. 
In line with (Kawiyah, 2015), it is shown that the development of scientific-based mathematics learning tools to improve student learning outcomes is considered effective for use with the percentage of students achieving KKM of more than $75 \%$. Research also shows that the results of effectiveness testing on learning tools to improve student learning outcomes are considered effective with completeness of student learning outcomes of $75 \%$ (Simanungkalit, 2016). The researcher then conducted an average difference test to see the difference in the ability to solve mathematical problems of the experimental class and the control class. Based on the t-test it was found that the significance level of $p<\propto=$ 0.05 . So it can be concluded that $\mathrm{HO}$ is rejected or there is a difference in the ability to solve mathematical problems between students who use mathematical learning tools that are developed with students who do not use learning tools that are developed.

Based on the observation sheet of the implementation of teacher activities in the learning process towards the use of syllabus and lesson plans, as well as the questionnaire of students' responses to the use of LKPD it can be concluded that the syllabus, lesson plans and LKPD meet the practicality criteria. Based on student learning outcomes, it can be concluded that the learning tools developed are effective for improving student learning outcomes. Based on the average difference test ( $\mathrm{t}$-test) it is known that there are differences in the ability to solve problems of students who use devices that are developed with those that do not use.

Evaluation stage is a stage to find out the strengths and weaknesses of learning tools that have been developed and implemented. One of the advantages gained from applying learning tools with the MASTER Plan technique is that students learn independently, explore for themselves information related to the material that has been learned and train students to infer the information that has been obtained with the help of mental maps. The weaknesses in the allocation of learning time. The time allocation provided tends to be inadequate, which results in the activity of communicating only a few people who have the opportunity to present.

\section{CONCLUSION}

This development research produces learning tools by applying the MASTER Plan technique to improve student learning outcomes of material number patterns. Learning tools are said to be very valid, very practical, and effective after going through the validation process by qualified experts, and grade VIII students to ensure practicality and effectiveness after going through the testing phase so that the learning outcomes of students increase after using it.

\section{REFERENCES}

Akbar, S. (2013). Instrumen Perangkat Pembelajaran. PT Remaja Rosdakarya.

Akinloye, G. M., Adu, E. O., Adu, K. O., \& Olawumi, K. B. (2020). Information and Communications Technology (ICT) and Teaching-Learning Capacity: The Classroom Management Interconnectivity. Journal of Social Sciences and 
Humanities, 17(7), 13-30.

Asmawati, E., \& Nurhayati, L. (2016). Penerapan Pendekatan Saintifik Untuk Meningkatkan Keterampilan Proses Siswa Pada Konsep Siklus Air. Jurnal Pedagogi Pendidikan Dasar, 4(1), 73-86.

Dina, A., \& Arifatud Dina, V. D. M. \& R. S. (2015). Implementasi Kurikulum 2013 Pada Perangkat Pembelajaran Model Discovery Learning Pendekatan Scientific terhadap Kemampuan Komunikasi Matematis Materi Geometri SMK. JKPM, 2(1), 22-31. https://doi.org/https://doi.org/10.26714/jkpm.2.1.2015.\%25p

Erita, S. (2013). Beberapa Model, Pendekatan, Strategi, Dan Metode Dalam Pembelajaran Matematika. Jurnal Kependidikan, 1(1), 1-13.

Fitri Nurhayati, Joko Widodo, E. S. (2015). Pengembangan Lks Berbasis Problem Based Learning ( $\mathrm{Pbl})$ Pokok Bahasan Tahap Pencatatan Akuntansi Perusahaan Jasa. The Journal of Economic Education, 4(1), 14-19.

Haris Mudjiman. (2006). Belajar Mandiri. Lembaga Pengembangan Pendidikan (LPP) UNS dan UPT Penerbitan dan Pencetakan UNS (UNS Press).

Heni Rahmadani, Yenita Roza, A. M. (2020). Design of Information and Technology Based Teaching Materials in Mathematics Subjects of IT High School Pekanbaru Students. Mathematics Education Journals, 4(1), 17-28.

Isna Rafianti, N. A. \& K. I. (2018). Pengembangan Perangkat Pembelajaran Matematika dalam Mendukung Kemampuan Abad 21. KALAMATIKA Jurnal Pendidikan Matematika, 3(1), 123-138.

Kawiyah, S. (2015). Pengembangan Perangkat Pembelajaran Matematika Berbasis Saintifik untuk Meningkatkan Kemampuan Pemecahan Masalah dan Prestasi Belajar Siswa. PYTHAGORAS: Jurnal Pendidikan Matematika, 10(2), 201. https://doi.org/10.21831/pg.v10i2.9163

Kemdikbud. (2013). Materi Pelatihan Guru: Implementasi Kurikulum 2013 SMP/MTs Matematika. Kemdikbud.

Legendari, M. A., \& Raharjo, H. (2016). Pengembangan Bahan Ajar Berbasis Audio Visual Terhadap Hasil Belajar Siswa Pada Materi Pokok Bangun Ruang Kubus Dan Balok Kelas Viii Di Smp N 1 Ciledug. Eduma: Mathematics Education Learning and Teaching, 5(1). https://doi.org/10.24235/eduma.v5i1.683

Li, J., Larsen, K., \& Abbasi, A. (2020). TheoryOn: A design framework and system for unlocking behavioral knowledge through ontology learning. MIS Quarterly, 1-48. http://ahmedabbasi.com/wp-content/uploads/J/Li_TheoryOn_MISQ.pdf

Muhammad Tajuddin, Endang Siti Astuti, Hamdani Husnan, A. M. (2015). Membangun Master Plan Teknologi Informasi Berbasis Needs Assessment (Tajuddin dkk.). Prosiding SNST Fakultas Teknik, 266-271.

Murda, N., \& Purwanti, P. D. (2017). Penerapan Strategi Pembelajaran Think Pair Shareuntuk Meningkatkan Kemampuan Membaca Intensif Siswa. International Journal of Elementary Education, 1(1), 11. https://doi.org/10.23887/ijee.v1i1.11434

Musa Thahir, Yenita Roza, A. M. (2018). Validity of learning website of kapita selekta mathematics course at UIN Suska Riau Students. Malikussaleh Journal of Mathematics Learning (MJML), 1(1), 19. https://doi.org/10.29103/mjml.v1i1.667

N. W. Siwardani, N. Dantes, I. A. S. (2015). Pengaruh Model Pembelajaran ADDIE Terhadap Pemahaman Konsep Fisika Dan Keterampilan Berpikir Kritis Siswa Kelas X SMA Negeri 2 Mengwi Tahun Pelajaran 2014/2015. Jurnal Administrasi Pendidikan, 6(1), 1-10.

Novrini, Siagian, P., \& Surya, E. (2015). Pengembangan Perangkat Pembelajaran 
Berorientasi Problem Based Learning Untuk Meningkatkan Kemampuan Visual Thinking Dalam Pemecahan Masalah Matematis Siswa Kelas VIII SMP. Jurnal Paradigma, 8(3), 84-97.

Persada, Y. I., Djatmika, E. T., \& Degeng, I. N. S. (2020). Pelaksanaan Pendekatan Scientific Dalam Pembelajaran Tematik. Jurnal Pendidikan: Teori, Penelitian, Dan Pengembangan, 5(1), 114-120.

Rahmadi, F. (2015). Pengembangan Perangkat Pembelajaran Berbasis Pemecahan Masalah Berorientasi Pada Kemampuan Penalaran dan Komunikasi Matematika. Jurnal Pendidikan Matematika, 10(2), 137-145.

Saylendra, N. P., \& Danial, E. (2015). Implementasi Pendekatan Saintifik dan Penilaian Otentik Dalam Pembelajaran Pendidikan Pancasila dan Kewarganegaraan di SMAN 7 Bogor. Jurnal Ilmiah Mimbar Demokrasi, 15(1), 17-41. https://doi.org/10.21009/jimd.v15i1.9109

Si, D., Moritz, S. A., Pfab, J., Hou, J., Cao, R., Wang, L., Wu, T., \& Cheng, J. (2020). Deep Learning to Predict Protein Backbone Structure from High-Resolution CryoEM Density Maps. Scientific Reports, 10(1), 1-22. https://doi.org/10.1038/s41598020-60598-y

Simanungkalit, R. H. (2016). Pengembangan Perangkat Pembelajaran untuk Meningkatkan Kemampuan Pemecahan Masalah Matematis Siswa SMP Negeri 12 Pematangsiantar. MUST: Journal of Mathematics Education, Science and Technology, 1(1), 39. https://doi.org/10.30651/must.v1i1.96

Tambunan, H. (2019). The Effectiveness of the Problem Solving Strategy and the Scientific Approach to Students' Mathematical Capabilities in High Order Thinking Skills. International Electronic Journal of Mathematics Education, 14(2), 293-302. https://doi.org/10.29333/iejme/5715

Thahir, M., Roza, Y., \& Murni, A. (2020). Website design of Capita Selekta Mathematics Course for Mathematics Education Students. Journal of Physics: Conference Series, 1470(1), 0-11. https://doi.org/10.1088/1742-6596/1470/1/012092

Widada, W., Herawaty, D., Andriyani, D. S., Marantika, R., Yanti, I. D., \& Falaq Dwi Anggoro, A. (2020). The Thinking Process of Students in Understanding The Concept of Graphs During Ethnomathematics Learning. Journal of Physics: Conference Series, 1470(1), 1-7. https://doi.org/10.1088/1742-6596/1470/1/012072 